DOI: https://doi.org/10.47405/mjssh.v6i10.1067

\begin{tabular}{|c|c|}
\hline & Malaysian Journal of Social Sciences and Humanities (MJSSH) \\
\hline Malaysian Journal of & Volume 6, Issue 10, October 2021 \\
\hline (Mulssh) & e-ISSN : 2504-8562 \\
\hline & $\begin{array}{l}\text { Journal home page: } \\
\text { www.msocialsciences.com }\end{array}$ \\
\hline
\end{tabular}

\title{
Kaedah Flipped Classroom dalam Pembelajaran Matematik di Peringkat Pengajian Tinggi : Sorotan Literatur Bersistematik
}

\author{
Md Saleh Bin Osman'1, Siti Mistima Maat ${ }^{1}$ \\ ${ }^{1}$ Fakulti Pendidikan, Universiti Kebangsaan Malaysia (UKM), Malaysia \\ Correspondence: Md Saleh Bin Osman (msaleho@yes.my)
}

\begin{abstract}
Abstrak
Pembelajaran yang berpusatkan pelajar semakin mendapat sambutan di kalangan tenaga pengajar. Pendekatan flipped classroom yang memerlukan penglibatan aktif para pelajar dalam perbincangan dan penyelesaian masalah mengubah keadaan tradisional pembelajaran. Kajian sistematik ini adalah untuk meninjau persepsi dan impak flipped classroom dalam pembelajaran Matematik di peringkat pengajian tinggi. Sebanyak 30 artikel yang berkaitan dari tahun 2017 sehingga 2021 dipilih dari dua pangkalan data iaitu Scopus dan Web of Science (WOS). Beberapa kriteria melibatkan jenis artikel, peserta kajian serta skop kajian telah ditetapkan bagi kajian ini. Hasil analisis mendapati bahawa para pelajar serta pengajar di peringkat kolej dan universiti mempunyai persepsi yang positif terhadap flipped classroom. Selain itu, terdapat tiga impak utama flipped classroom terhadap pelajar iaitu dari segi pencapaian Matematik, sikap pelajar dan penglibatan dalam pembelajaran telah dikenal pasti. Pencapaian pelajar dalam subjek Matematik didapati meningkat serta sikap pelajar menjadi positif terhadap pembelajaran. Pelajar juga didapati lebih terbuka dalam interaksi di dalam kelas serta aktif terlibat dalam pembelajaran. Dapatan kajian diharap meyakinkan tenaga pengajar bagi menggunakan kaedah flipped classroom di dalam kelas dengan lebih berkesan.
\end{abstract}

Kata kunci: flipped classroom, persepsi, impak, matematik

\section{Flipped Classroom Methods in Mathematics Learning in Higher Education: Systematic Literature Review}

\begin{abstract}
Student-centered learning is gaining popularity among educators. The flipped classroom approach that requires the active involvement of students in discussion and problem solving changes the traditional state of learning. This systematic study was to survey the perceptions and impact of flipped classroom in Mathematics learning at the tertiary level. A total of 30 related articles from 2017 to 2021 were selected from two databases namely Scopus and Web of Science (WOS). Several criteria involving the type of article, study participants as well as the scope of the study have been set for this study. The results of the analysis found that students and instructors in colleges and universities have a positive perception of flipped classroom. In addition, there are three main impacts of flipped classroom on students namely in terms of Mathematics achievement, student attitudes and involvement in learning. Student's achievement in the subject of Mathematics was found to increase and their attitudes became positive towards learning. Students are also found to be more open in interaction in the class and actively involved in learning. The findings of the study are expected to convince the instructors to use the flipped classroom method in the classroom more effectively.
\end{abstract}


Keywords: flipped classroom, perception, impact, mathematics

\section{Pengenalan}

Flipped classroom adalah satu kaedah pedagogi yang biasa digunakan bagi peringkat pengajian tinggi selepas sistem persekolahan. Ia adalah satu kaedah yang berpandukan model blended learning yang menukar paradigma kaedah pengajaran tradisional dari segi tugasan dan pendekatan pengajaran di dalam kelas (Farmus et al., 2020). Idea di sebalik kaedah ini memerlukan maklumat dan panduan pengajaran dijalankan di luar masa kelas. Masa kuliah sebaliknya digunakan untuk interaksi dan pembangunan konseptual menerusi perbincangan di kalangan pelajar, menyelesaikan masalah dan mengaplikasikan pengetahuan konseptual. Flipped classroom merupakan salah satu kaedah yang sesuai dilaksanakan dalam sistem pendidikan Malaysia di peringkat pengajian tinggi. Kaedah pedagogi ini dilihat mampu menerapkan kemahiran aras tinggi dalam kalangan pelajar terutama apabila penggunaan teknologi dijalinkan bersama.

Kelemahan pelajar dalam subjek Matematik sering diutarakan dan menjadi kajian para penyelidik. Pelbagai inovasi dalam pengajaran dalam subjek ini telah dicadangkan bagi mengatasi masalah ini (Butterworth et al., 2011). Situasi ini tambah meruncing apabila kemahiran berfikir aras tinggi dilihat menjadikan pelajar semakin risau dan bersikap negatif terhadap subjek Matematik. Menurut Liew dan Matora (2020), flipped classroom merupakan antara pilihan yang dilihat tepat digunakan dalam sistem pendidikan Malaysia bagi menerapkan kemahiran aras tinggi. Ini disebabkan penggunaan unsur teknologi dalam pedagogi ini dilihat seiring dengan cita rasa serta gaya kehidupan pelajar yang berfokuskan gadjet dan aplikasi. Walau bagaimanapun, persepsi pensyarah dan pelajar pengajian tinggi perlu dilihat lebih mendalam bagi menjamin keberkesanan kaedah ini dalam pengajaran.

\section{Sorotan Literatur}

Kepentingan subjek Matematik pada era moden menjadi topik yang sering dibincangkan dan dikaji. Aspek-aspek pedagogi yang berkesan berkaitan subjek ini menjadi tumpuan pengkaji bagi membolehkan objektif pembelajaran tercapai. Braun et al. (2017) telah menegaskan kepentingan tenaga pengajar untuk mencari kaedah yang lebih baik dalam mengajar Matematik. Kepentingan ini tidak terbatas kepada sesuatu peringkat persekolahan atau pengajian malahan meliputi semua peringkat pendidikan. Kaedah pedagogi yang berkesan ini perlu efektif dan mendatangkan motivasi yang baik kepada pelajar. Kaedah yang dirangka ini juga perlu melibatkan kaedah pembelajaran aktif yang memfokuskan kepada penglibatan pelajar dalam pelbagai aktiviti pembelajaran. Aktiviti pembelajaran tersebut meliputi pembacaan, penulisan, perbincangan dan kemahiran penyelesaian masalah yang meningkatkan kemahiran aras tinggi pelajar.

Menurut Fernández-Martín et al. (2020), pelaksanaan flipped classroom dipertimbangkan sebagai salah satu pedagogi yang terbaru dan relevan sejak kebelakangan ini. Dalam bidang berkaitan Matematik, kesesuaian kaedah pedagogi ini telah mendorong tenaga pengajar untuk mempraktikkan dalam pengajaran harian. Memandangkan penekanan terhadap pengajaran aktif dan berpusatkan pelajar menjadi keutamaan, tidak hairan kaedah ini menjadi pilihan tenaga pengajar terutama di peringkat pengajian tinggi. Kecanggihan teknologi serta kemudahan akses kepada maklumat menjadi pemacu kepada penggunaan flipped classroom di mana pembelajaran bukan sahaja terhad di dalam kelas.

Kekangan pembelajaran tradisional yang melibatkan suasana pembelajaran yang pasif di kalangan pelajar dilihat menjadi halangan kepada minat dan sikap yang positif terhadap subjek Matematik. Kaedah flipped classroom dilihat dapat mengubah persepsi dan interaksi pelajar pada peringkat pengajian tinggi terhadap subjek Matematik. Pelajar menunjukkan interaksi dan penglibatan yang lebih baik dari segi pengetahuan dan persediaan di dalam kelas (Al-Zoubi \& Suleiman, 2021). Selain itu, para pelajar didapati lebih menyukai kaedah baru dalam pembelajaran kerana berpendapat bahawa ia menjadikan proses mempelajari Matematik lebih menarik dan mudah difahami. Tidak terbatas kepada 
pelajar, para pensyarah juga memberi pandangan yang positif terhadap pengajaran menggunakan flipped classroom dalam kuliah mereka.

Jaster (2017) telah menjalankan kajian terhadap persepsi pelajar dan juga pensyarah bagi subjek Algebra. Hasil kajian mendapati bahawa pelajar beranggapan bahawa kaedah flipped classroom memerlukan lebih banyak masa serta kurang diminati berbanding dengan kaedah tradisional. Ini bertentangan dengan kajian Khan dan Watson (2018) di kalangan 158 pelajar yang mendapati bahawa majoriti menyukai kaedah ini berbanding kelas tradisional. Pelajar berumur 18 sehingga 19 dilihat lebih cenderung disebabkan oleh tabiat golongan ini ke atas aktiviti dalam talian. Pelajar juga menunjukkan prestasi lebih baik serta kefahaman lebih mendalam dalam subjek yang dipelajari. Ini seterusnya memberi impak kepada keputusan yang diperoleh dalam peperiksaan yang diambil oleh mereka. Dari sudut pensyarah, kaedah ini memerlukan kemahiran dan usaha yang berterusan bagi membimbing pelajar dalam menjalankan flipped classroom. Namun kesan yang didapati oleh pensyarah di dalam kelas adalah kelas lebih interaktif, menyeronokkan serta berbaloi berbanding kelas tradisional.

Kajian-kajian lepas juga mendapati bahawa aplikasi flipped classroom bukan hanya memberi kesan kepada persepsi pelajar malahan turut menyumbang kepada aspek pencapaian akademik. Impak terhadap pencapaian dalam subjek berkaitan Matematik berkait rapat dengan pembelajaran pelajar yang tidak tertumpu di dalam kelas sahaja malahan sudah bermula sebelum sesi pembelajaran bermula. Buch dan Warren (2017) mendapati bahawa pelajar yang mengikuti pembelajaran secara flipped classroom mendapat keputusan yang lebih baik berbanding pelajar yang diajar dengan cara tradisional. Perbandingan markah yang dijalankan antara 2 kumpulan pelajar mendapati terdapat peningkatan yang ketara di kalangan mereka. Ini adalah bertepatan dengan beberapa kajian lain yang turut dijalankan bagi melihat impak flipped classroom kepada pelajar dalam peringkat pengajian tinggi. Ini disokong oleh kajian Carter et al. (2018) yang menyatakan video pembelajaran yang baik apabila dijadikan bahan kolaboratif di dalam kelas dapat meningkatkan keberhasilan pelajar.

\section{Metod Kajian}

Pencarian bahan bagi sorotan literatur biasanya diperoleh secara maya menggunakan bibliografi atau pangkalan data artikel, laman web dan lain-lain. Pencarian artikel dalam talian dibuat kerana menjimatkan masa serta mudah didapati. Pilihan pangkalan data yang banyak juga memudahkan pencarian dan memberi pilihan yang banyak bagi pengkaji dalam mendapatkan artikel bagi analisis ini. Lima langkah yang dicadangkan oleh Khan et al. (2003) digunakan bagi melaksanakan tinjauan sistematik ini seperti dalam Rajah 1.

\section{Persoalan kajian}

Kajian melalui analisis kandungan ini diharap dapat memberikan gambaran yang lebih menyeluruh terhadap isu-isu berkaitan flipped classroom. Tujuan utama kajian ini dijalankan adalah untuk meneroka isu-isu berkaitan dengan flipped classroom. Isu-isu berkaitan persepsi terhadap kaedah ini di kalangan pensyarah serta pelajar di peringkat pengajian tinggi menjadi tumpuan. Selain itu impak atau kesan flipped classroom terhadap pembelajaran Matematik turut diselusuri. Justeru itu, sorotan literatur secara sistematik ini dijalankan untuk menjawab persoalan-persoalan berikut:

i. Apakah persepsi pensyarah dan pelajar terhadap flipped classroom?

ii. Apakah impak flipped classroom terhadap pembelajaran subjek Matematik di peringkat pengajian tinggi?

\section{Mengenal pasti artikel yang berkaitan}

Kajian sorotan literatur secara sistematik ini menggunakan pendekatan kualitatif dengan menerapkan kaedah analisis kandungan sebagai reka bentuk kajian. Bagi mencari artikel yang memenuhi kriteria kajian ini, pengkaji telah memilih dua pangkalan data iaitu Scopus dan Web of Science (WOS). 
DOI: https://doi.org/10.47405/mjssh.v6i10.1067

Pencarian artikel dalam dua pangkalan data ini telah dilakukan antara bulan April 2021 hingga Mei 2021 dengan menggunakan beberapa gabungan kata kunci seperti "flipped classroom" AND "mathematics", "inverted classroom" AND "mathematics", "flipped classroom" AND "achivement", "flipped classroom", "impact" dan "effect".

Rajah 1: Langkah-langkah Tinjauan Literatur Sistematik

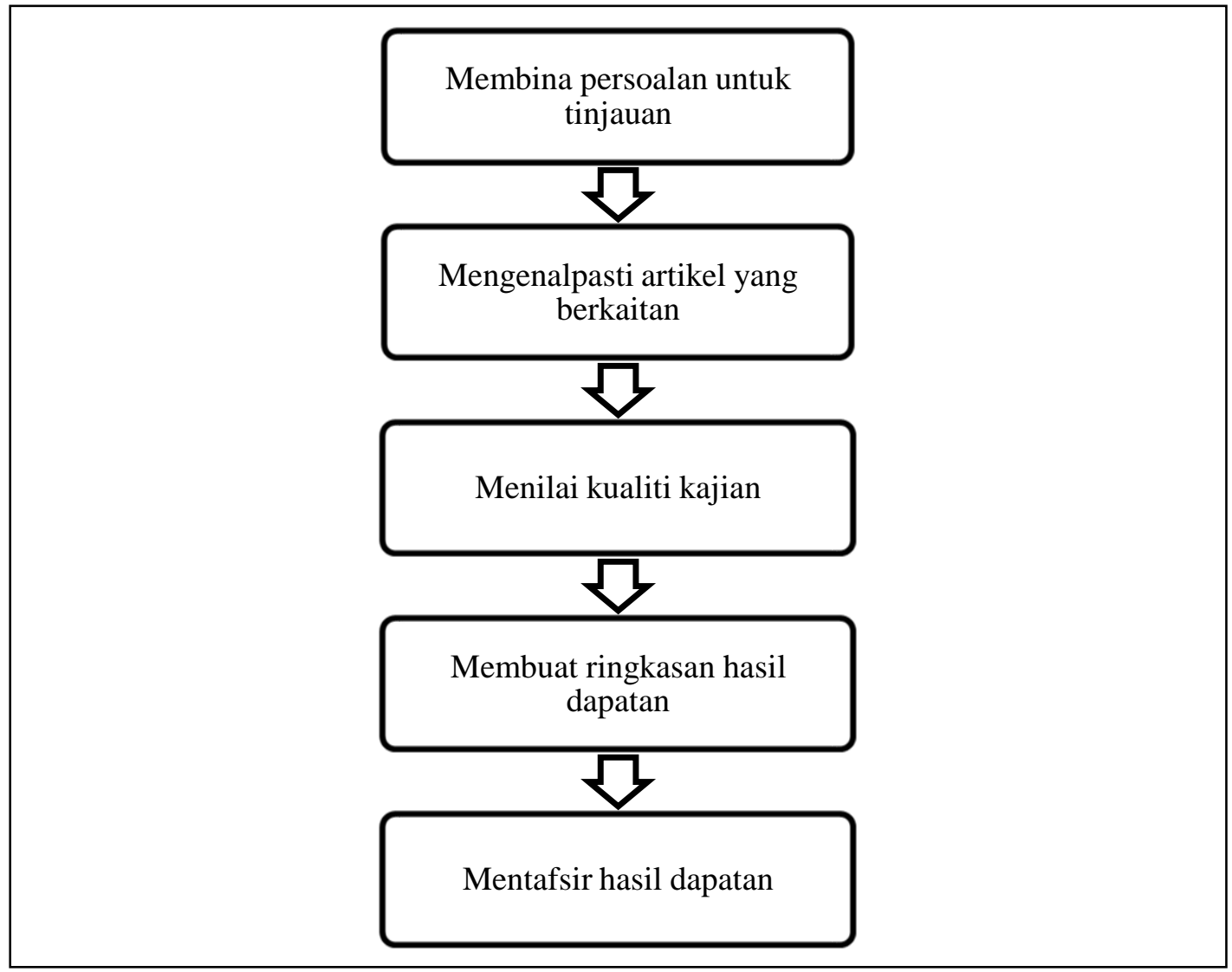

Sumber: Khan et al. (2003)

\section{Menilai kualiti kajian}

Setelah menentukan pangkalan data serta kata kunci yang berkaitan dengan persoalan kajian, beberapa kriteria inklusif dan eksklusif ditetapkan. Terdapat 4 kriteria inklusif iaitu yang diterima adalah seperti di bawah:

i. Artikel yang diterbitkan dalam tempoh masa 5 tahun terkini iaitu dari Januari 2017 sehingga Mei 2021.

ii. Artikel yang lengkap (full text) dan telah disemak (peer reviewed).

iii. Artikel daripada jurnal sahaja.

iv. Artikel yang berkaitan dengan pelajar atau pensyarah di peringkat pengajian tinggi sahaja sama ada di dalam atau luar negara.

Kriteria eksklusif yang ditetapkan adalah artikel dari prosiding, disertasi atau tesis, manuskrip atau sumber rujukan lain. Selain itu, semua artikel yang berkaitan sekolah rendah mahupun sekolah menengah dikecualikan daripada menjadi bahan rujukan bagi kajian ini. 


\section{Membuat ringkasan hasil dapatan}

Bahagian ini akan menerangkan bagaimana pemilihan kajian dalam tinjauan sistematik berdasarkan kaedah Preferred Reporting Items for Systematic reviews and Meta-Analyses (PRISMA). Kaedah ini membantu pengkaji menentukan kajian yang diperlukan berdasarkan persoalan kajian (Jamaludin et al., 2020). Berdasarkan Moher et al. (2009), terdapat empat langkah dalam carta alir PRISMA bagi menentukan kajian yang bersesuaian dengan kehendak pengkaji iaitu mengenal pasti (Identification), pemeriksaan (Screening), kelayakan (Eligibility) dan terpilih (Included).

Rajah 2: Carta alir bagi pencarian data menggunakan kaedah PRISMA

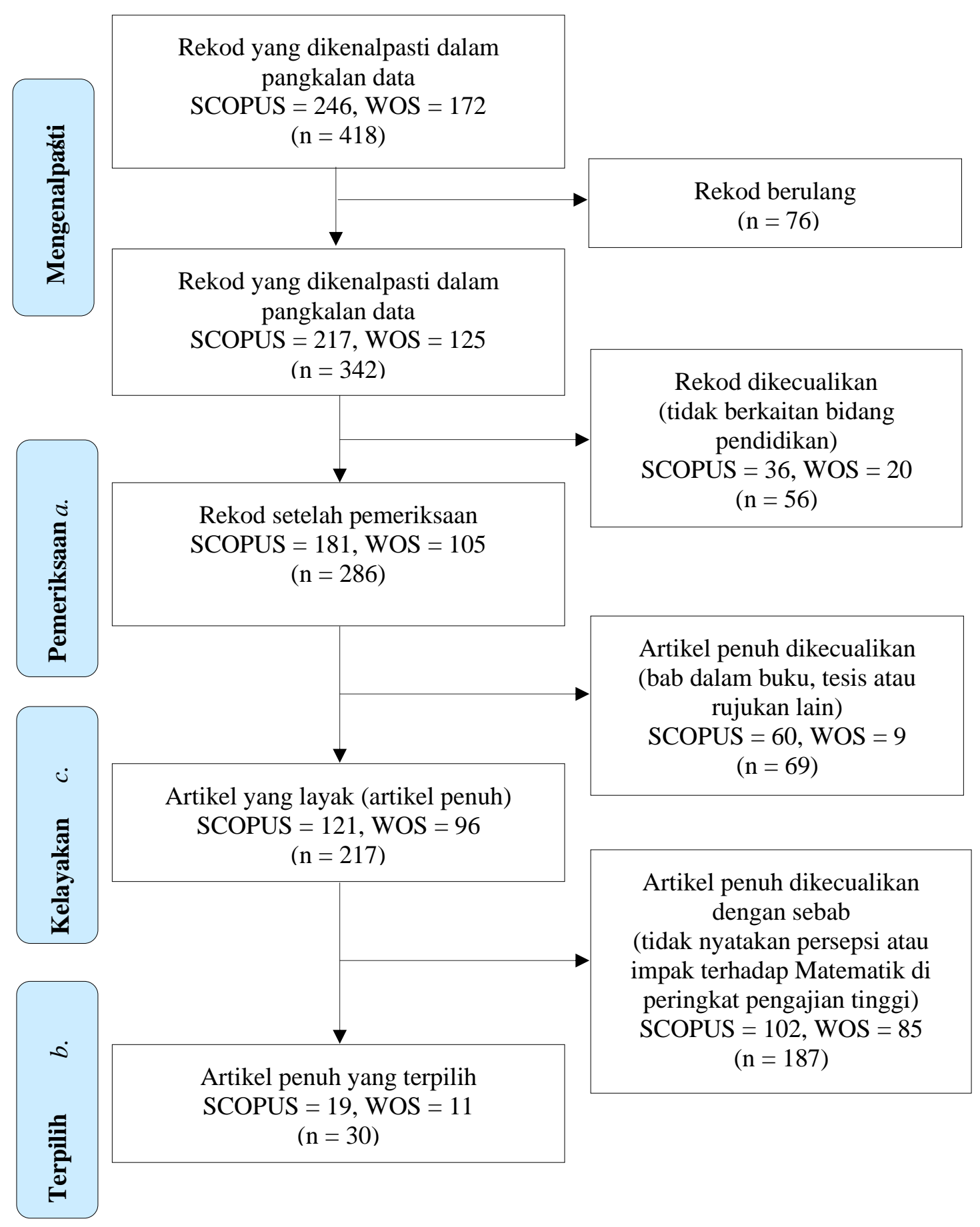

Sumber: Moher et al. (2009) 
Dalam peringkat ini, sebarang kajian yang berkaitan dengan persepsi atau impak flipped classroom dalam pembelajaran Matematik akan dikumpulkan. Berdasarkan kriteria pertama yakni peringkat pertama dalam pencarian artikel dalam pangkalan data, sebanyak 418 artikel telah dikenal pasti dimana 246 artikel daripada Scopus dan 172 artikel daripada WOS. Seterusnya, artikel ini disaring bagi mengelakkan artikel yang berulang atau sama dalam pangkalan data yang dicari. Sebanyak 342 artikel dipilih setelah proses saringan ini dilakukan. Sebanyak 56 artikel telah ditolak memandangkan artikel berkenaan tidak berkaitan bidang pendidikan. Ini menjadikan hanya 286 artikel yang berkaitan dengan flipped classroom dipilih.

Pada peringkat kelayakan, saringan dilakukan dengan memilih hanya artikel penuh daripada jurnal yang telah disemak dan berkaitan dengan persoalan kajian yang ingin diselidiki. Daripada jumlah 286 artikel, sebanyak 69 artikel ditolak kerana merangkumi bab dalam buku, prosiding, kertas kerja prosiding, disertasi atau tesis, manuskrip atau sumber rujukan lain. Peringkat akhir iaitu pemilihan artikel dilakukan dengan teliti bagi menjawab persoalan kajian. Sebanyak 30 artikel telah dipilih seperti digambarkan secara ringkas dalam Rajah 2.

\section{Mentafsir hasil dapatan}

Berdasarkan 30 artikel yang dipilih, senarai artikel disusun mengikut tahun kajian seperti dalam Jadual 1.

Jadual 1: Senarai artikel yang diterbitkan mengikut tahun

\begin{tabular}{|c|c|c|c|}
\hline Tahun & Bil & Penulis & Tajuk \\
\hline \multirow{11}{*}{2017} & 1 & Zengin & $\begin{array}{l}\text { Investigating the use of the Khan Academy and mathematics } \\
\text { software with a flipped classroom approach in mathematics } \\
\text { teaching }\end{array}$ \\
\hline & 2 & $\begin{array}{l}\text { Buch \& } \\
\text { Warren }\end{array}$ & $\begin{array}{l}\text { The Flipped Classroom: Implementing Technology To Aid In } \\
\text { College Mathematics Student's Success }\end{array}$ \\
\hline & 3 & Boevé et al. & $\begin{array}{l}\text { Implementing the flipped classroom: an exploration of study } \\
\text { behaviour and student performance }\end{array}$ \\
\hline & 4 & Johnston & $\begin{array}{l}\text { Implementing a flipped classroom approach in a university } \\
\text { numerical methods mathematics course }\end{array}$ \\
\hline & 5 & Novak et al. & $\begin{array}{l}\text { Flip or flop? Students' perspectives of a flipped lecture in } \\
\text { mathematics }\end{array}$ \\
\hline & 6 & $\begin{array}{l}\text { Tisdell \& } \\
\text { Loch }\end{array}$ & $\begin{array}{l}\text { How useful are closed captions for learning mathematics via } \\
\text { online video? }\end{array}$ \\
\hline & 7 & Shinaberger & $\begin{array}{l}\text { Components of a Flipped Classroom Influencing Student Success } \\
\text { in an Undergraduate Business Statistics Course }\end{array}$ \\
\hline & 8 & Foldnes & $\begin{array}{l}\text { The impact of class attendance on student learning in a flipped } \\
\text { classroom }\end{array}$ \\
\hline & 9 & Li et al. & $\begin{array}{l}\text { Cooperation learning of flip teaching style on the } M B A \\
\text { mathematics education efficiency }\end{array}$ \\
\hline & 10 & Wasserman & Exploring Flipped Classroom Instruction in Calculus III \\
\hline & 11 & Jaster & $\begin{array}{l}\text { Student and Instructor Perceptions of a Flipped College Algebra } \\
\text { Classroom }\end{array}$ \\
\hline \multirow{4}{*}{2018} & 12 & Froehlich & $\begin{array}{l}\text { Non-technological learning environments in a technological } \\
\text { world: Flipping comes to the aid }\end{array}$ \\
\hline & 13 & $\begin{array}{l}\text { Khan \& } \\
\text { Watson }\end{array}$ & $\begin{array}{l}\text { The flipped classroom with tutor support: An experience in a level } \\
\text { one statistics unit }\end{array}$ \\
\hline & 14 & $\begin{array}{l}\text { Cronhjort et } \\
\text { al. }\end{array}$ & Improved engagement and learning in flipped-classroom calculus \\
\hline & 15 & Albalawi & $\begin{array}{l}\text { The effect of using flipped classroom in teaching calculus on } \\
\text { students' achievements at university of Tabuk }\end{array}$ \\
\hline
\end{tabular}


DOI: https://doi.org/10.47405/mjssh.v6i10.1067

16 Nielsen et The impact of a flipped classroom model of learning on a large al. undergraduate statistics class

17 Lopes \& Perception and performance in a flipped Financial Mathematics Soares classroom

18 Carter et al. The Flipped Classroom in a Terminal College Mathematics Course for Liberal Arts Students

19 Turra et al. Flipped classroom experiences and their impact on engineering students' attitudes towards university-level mathematics

20 Umametal. An application of flipped classroom in mathematics teacher 2019 education programme

21 Romero- $\quad$ The Flipped Learning Model In Online Education For Secondary García et al. Teachers

22 Immekus Flipping Statistics Courses in Graduate Education: Integration of Cognitive Psychology and Technology

23 Dori et al. Mathematics for Computer Science: A Flipped Classroom with an Optional Project

24 Moreno et An assessment of the impact of teachers' digital competence on the al. quality of videos developed for the flipped math classroom

202025 Maldonado Modelling dependency structures produced by the introduction of a \& Morales flipped classroom

26 Pozo Correlational analysis of the applicability of flipped learning Sánchez et according to the particularities of teaching practice al.

27 Wood et al. Lecture capture as an element of the digital resource landscape - a qualitative study of flipped and non-flipped classrooms

28 Al-Zoubi \& Flipped classroom strategy based on critical thinking skills: Suleiman Helping fresh female students acquiring derivative concept

202129 Jeong \& Flipped-ocn method in mathematics learning to analyze the González attitudes of pre-service teachers

Gómez

30 Salas-Rueda Use of flipped classroom in the marketing career during the educational process on financial mathematics

\section{Hasil Kajian}

Kajian yang dihimpunkan telah diterbitkan di 16 buah negara sepanjang tahun 2017 sehingga tahun 2021. Majoriti kajian adalah daripada negara Amerika Syarikat iaitu sebanyak 8 artikel. Kajian yang lain adalah dari negara Sepanyol sebanyak 5 artikel, Australia sebanyak 3 artikel dan Arab Saudi sebanyak 2 artikel. Sebanyak satu artikel dipilih dari negara-negara lain iaitu dari United Kingdom, Turki, Austria, Belanda, Chile, Indonesia, Sweden, New Zealand, Portugal, Norway, China dan Mexico.

Jadual 2: Lokasi dan jumlah kajian mengikut tahun

\begin{tabular}{|c|c|c|c|c|c|c|}
\hline \multirow[t]{2}{*}{ Negara } & \multicolumn{5}{|c|}{ Tahun } & \multirow[t]{2}{*}{ Jumlah } \\
\hline & 2017 & 2018 & 2019 & 2020 & 2021 & \\
\hline UK & & & & & 1 & 1 \\
\hline Arab Saudi & & I & & & I & 2 \\
\hline Turki & I & & & & & 1 \\
\hline USA & IIII & // & l & I & & 8 \\
\hline Sepanyol & & & I & /I/ & I & 5 \\
\hline Austria & & I & & & & 1 \\
\hline Belanda & I & & & & & 1 \\
\hline Chile & & & I & & & 1 \\
\hline
\end{tabular}


DOI: https://doi.org/10.47405/mjssh.v6i10.1067

\begin{tabular}{|c|c|c|c|c|c|c|}
\hline Indonesia & & & I & & & 1 \\
\hline Sweden & & l & & & & 1 \\
\hline New Sealand & I & & & & & 1 \\
\hline Australia & // & l & & & & 3 \\
\hline Portugal & & I & & & & 1 \\
\hline Norway & I & & & & & 1 \\
\hline China & I & & & & & 1 \\
\hline Mexico & & & & & I & 1 \\
\hline Jumlah & 11 & 7 & 4 & 4 & 4 & 30 \\
\hline
\end{tabular}

Berdasarkan Jadual 3, terdapat tiga jenis penyelidikan yang dilakukan oleh pengkaji dalam artikel yang dipilih. Tiga jenis penyelidikan tersebut adalah kuantitatif, kualitatif dan gabungan.

Jadual 3: Analisis jenis penyelidikan dan reka bentuk kajian

\begin{tabular}{lll}
\hline Penyelidikan & Reka Bentuk Kajian & Kajian \\
\hline Kuantitatif & Eksperimental \& & (Albalawi, 2018; Buch \& Warren, 2017; Carter et \\
& Kuasi-Eksperimental & al., 2018; Cronhjort et al., 2018; Dori et al., 2020; \\
& Kolerasi & Immekus, 2019; Jeong \& González-Gómez, 2021; \\
& Kajian Tinjauan & Johnston, 2017; Khan \& Watson, 2018; Li et al., \\
& 2017; Maldonado \& Morales, 2020; Moreno et al., \\
& 2020; Nielsen et al., 2018; Novak et al., 2017; \\
& Pozo Sánchez et al, 2020; Shinaberger, 2017; \\
& Turra et al., 2019; Wasserman, 2017)
\end{tabular}

\begin{tabular}{|c|c|c|}
\hline Kualitatif & $\begin{array}{l}\text { Kajian Kes } \\
\text { Naratif }\end{array}$ & $\begin{array}{l}\text { (Foldnes, 2017; Lopes \& Soares, 2018; Romero- } \\
\text { García et al., 2019; Wood et al., 2021) }\end{array}$ \\
\hline $\begin{array}{l}\text { Kuantitatif \& } \\
\text { Kualitatif } \\
\text { (mixed method) }\end{array}$ & & $\begin{array}{l}\text { (Al-Zoubi \& Suleiman, 2021; Boevé et al., 2017; } \\
\text { Froehlich, 2018; Jaster, 2017; Salas-Rueda, 2021; } \\
\text { Tisdell \& Loch, 2017; Umam et al., 2019; Zengin, } \\
\text { 2017) }\end{array}$ \\
\hline
\end{tabular}

Berdasarkan Jadual 4, persepsi berkenaan flipped classroom dilihat dari sudut pandangan pelajar dan pensyarah. Dari sudut pandangan pelajar dan pensyarah, persepsi boleh dilihat sama ada mereka mempunyai tanggapan umum yang positif atau negatif. Ini termasuk penerimaan, kelemahan dan kelebihan yang dirasakan oleh responden terhadap kaedah ini. Selain itu, kepentingan flipped classroom dari sudut pandangan pelajar turut dilihat iaitu sama ada efektif dalam memberi kefahaman dalam pembelajaran. Persepsi juga dilihat dari segi kepentingan dan keterbukaan pelajar dalam menerima kaedah ini berbanding dengan kaedah tradisional pembelajaran.

Jadual 4: Persepsi terhadap flipped classroom

\begin{tabular}{ll}
\hline Kategori & Persepsi terhadap flipped classroom \\
\hline Pelajar & - tanggapan positif atau negatif \\
& - efektif \\
& - penting guna flipped classroom \\
& - terbuka terima flipped classroom
\end{tabular}

Pensyarah

- tanggapan positif atau negatif

Berdasarkan Jadual 5, impak flipped classroom terhadap pelajar boleh dilihat dari segi pencapaian akademik dan perubahan dalam pembelajaran. Impak terhadap pencapaian akademik meliputi gred 
atau skor dalam peperiksaan yang diambil oleh pelajar. Ini dilihat menerusi pencapaian atau peningkatan markah yang diperoleh oleh pelajar dalam ujian yang dijalankan oleh pensyarah. Selain itu, pencapaian akademik juga dilihat dari segi pentaksiran terhadap ilmu dan kemahiran melalui projek atau penyelesaian masalah yang diberikan oleh pensyarah. Kadar perubahan dalam prestasi akademik turut dirangkum sebagai pencapaian akademik. Impak flipped classroom dari segi perubahan dalam pembelajaran dapat dilihat daripada sikap terhadap subjek, tabiat belajar dan hasil pembelajaran. Ini dilihat menerusi penglibatan, respons serta cara pelajar menjalankan tugas yang diberikan oleh pensyarah di dalam dan luar kelas.

Jadual 5: Impak flipped classroom terhadap pencapaian pelajar

\begin{tabular}{ll}
\hline Kategori & $\begin{array}{l}\text { Impak flipped classroom terhadap pelajar } \\
\text { (berdasarkan artikel) }\end{array}$ \\
\hline Pencapaian akademik & - Gred/skor dalam peperiksaan/ujian. \\
& - Pentaksiran terhadap ilmu dan kemahiran \\
& - Kadar perubahan dalam prestasi akademik \\
\hline Perubahan dalam pembelajaran & - Sikap terhadap subjek \\
& - Tabiat belajar \\
- Hasil pembelajaran \\
\hline
\end{tabular}

Berdasarkan Jadual 6, didapati bahawa 7 artikel membincangkan tentang persepsi pelajar dan pensyarah terhadap flipped classroom dan 15 artikel membincangkan tentang impak flipped classroom. Selain itu, 8 artikel membincangkan kedua-dua persoalan kajian berkenaan persepsi serta impak flipped classroom.

Jadual 6: Hasil dapatan keseluruhan daripada kajian lepas

\begin{tabular}{|c|c|c|c|c|}
\hline \multirow[b]{2}{*}{ Penulis } & \multicolumn{2}{|c|}{ Persepsi } & \multicolumn{2}{|r|}{ Impak } \\
\hline & Pelajar & Pensyarah & $\begin{array}{c}\text { Pencapaian } \\
\text { akademik }\end{array}$ & $\begin{array}{l}\text { Perubahan dalam } \\
\text { pembelajaran }\end{array}$ \\
\hline Albalawi (2018) & & & $*$ & \\
\hline Al-Zoubi \& Suleiman (2021) & $*$ & $*$ & & $*$ \\
\hline Boevé et al. (2017) & $*$ & & $*$ & $*$ \\
\hline Buch \& Warren (2017) & & & $*$ & \\
\hline Carter et al. (2018) & & & $*$ & \\
\hline Cronhjort et al. (2018) & & & $*$ & \\
\hline Dori et al. (2020) & & & $*$ & \\
\hline Foldnes (2017) & & & $*$ & \\
\hline Froehlich (2018) & & & & $*$ \\
\hline Immekus (2019) & $*$ & & & \\
\hline Jaster (2017) & * & $*$ & & \\
\hline Jeong \& González-Gómez (2021) & & & & $*$ \\
\hline Johnston (2017) & * & & & $*$ \\
\hline Khan \& Watson (2018) & * & & $*$ & $*$ \\
\hline Li et al. (2017) & * & & $*$ & \\
\hline Lopes \& Soares (2018) & & & $*$ & \\
\hline Maldonado \& Morales (2020) & & & $*$ & \\
\hline Moreno et al. (2020) & * & & & \\
\hline Nielsen et al. (2018) & * & & $*$ & \\
\hline Novak et al. (2017) & & & & $*$ \\
\hline Pozo Sánchez et al. (2020) & & $*$ & & \\
\hline Romero-García et al. (2019) & $*$ & & $*$ & \\
\hline Salas-Rueda (2021) & $*$ & & & \\
\hline
\end{tabular}


Shinaberger (2017)

Tisdell \& Loch (2017) DOI: https://doi.org/10.47405/mjssh.v6i10.1067

Turra et al. (2019)

Umam et al. (2019)

Wasserman (2017)

Wood et al. (2021)

Zengin (2017)

$\begin{array}{lll}* & * & * \\ & & * \\ * & & * \\ * & * & *\end{array}$

* Aspek atau konstruk berkaitan yang dikaji

\section{Perbincangan}

\section{Persepsi pelajar dan pensyarah terhadap flipped classroom}

\section{Pelajar}

Secara keseluruhan, kajian menunjukkan bahawa pelajar di peringkat pengajian tinggi mempunyai persepsi yang positif terhadap flipped classroom (Al-Zoubi \& Suleiman, 2021; Immekus, 2019; Jaster, 2017; Johnston, 2017; Khan \& Watson, 2018; Li et al., 2017; Moreno et al., 2020; Nielsen et al., 2018; Romero-García et al., 2019; Salas-Rueda, 2021; Tisdell \& Loch, 2017; Wood et al., 2021). Pelajar menyatakan bahawa kaedah pengajaran ini memudahkan pembelajaran mereka di mana multitasking dapat dilakukan di dalam kelas. Selain itu, pelajar juga beranggapan bahawa belajar Matematik menjadi mudah apabila flipped classroom dijalankan dalam kelas (Al-Zoubi \& Suleiman, 2021). Dari segi jantina, kajian yang dijalankan oleh Khan dan Watson (2018) mendapati bahawa pelajar perempuan lebih menyukai kaedah ini berbanding pelajar lelaki. Walaubagaimanapun, terdapat juga persepsi pelajar yang bercampur baur terhadap flipped classroom (Boevé et al., 2017; Wasserman, 2017). Persepsi ini wujud disebabkan oleh sebahagian pelajar yang lebih menyukai kaedah pembelajaran tradisional dan tidak ingin mengubah kepada sesuatu yang baru.

\section{Pensyarah}

Tidak begitu banyak kajian yang dijalankan bagi melihat persepsi pensyarah terhadap flipped classroom. Ini mungkin disebabkan fokus pengkaji tertumpu kepada pelajar dalam kajian mereka. Terdapat pensyarah yang menyatakan bahawa flipped classroom lebih mudah dalam mengajar subjek Matematik (Al-Zoubi \& Suleiman, 2021) namun kekangan pengetahuan menyebabkan aplikasi dalam kelas tidak dapat dijalankan (Pozo Sánchez et al., 2020)

\section{Impak terhadap pencapaian pelajar}

\section{Pencapaian akademik}

Hampir keseluruhan kajian mendapati kaedah flipped classroom meningkatkan pencapaian pelajar dalam subjek berkaitan Matematik kecuali Boevé et al. (2017). Peningkatan ini bukan sahaja dari segi peningkatan dalam markah peperiksaan malahan peratus gagal juga berkurang (Cronhjort et al., 2018). Kajian Albalawi (2018) menunjukkan bahawa pencapaian pelajar yang diajar menggunakan flipped classroom lebih baik berbanding kaedah tradisional. Ini disokong oleh kajian Buch dan Warren (2017) yang mendapati bahawa terdapat peningkatan dalam pencapaian pelajar dalam peperiksaan akhir bagi subjek yang diambil oleh pelajar. Selain dari meningkatkan pencapaian pelajar, kaedah flipped classroom juga didapati mengurangkan jurang pencapaian antara pelajar yang mempunyai bangsa yang berbeza (Carter, Carter \& Foss, 2018). Ini disebabkan oleh peningkatan penyertaan pelajar dalam aktiviti di dalam kelas serta intervensi yang dijalankan oleh pensyarah dalam kelas. 


\section{Perubahan dalam pembelajaran}

Persepsi yang positif oleh pelajar terhadap kaedah flipped classroom diharap memberi perubahan yang baik kepada pembelajaran mereka. Kajian menunjukkan bahawa flipped classroom dapat mengubah sikap pelajar serta memberi lebih kefahaman dalam pembelajaran mereka (Al-Zoubi \& Suleiman, 2021; Froehlich, 2018; Jeong \& González-Gómez, 2021; Khan \& Watson, 2018; Novak et al., 2017; Shinaberger, 2017; Turra et al., 2019; Umam et al., 2019; Zengin, 2017). Pelajar juga dilihat memberi interaksi dan penglibatan yang lebih aktif di dalam kelas. Dalam kajian yang dijalankan oleh Froehlich (2018), perubahan sikap dan hasil pembelajaran yang baik terhasil melalui flipped classroom walaupun dalam keadaan kekurangan teknologi di dalam kelas.

\section{Kesimpulan}

Kaedah flipped classroom dilihat sesuai dan berkesan dalam pengajaran subjek Matematik. Persepsi yang positif oleh pelajar pada peringkat pengajian tinggi diharap meyakinkan para pensyarah untuk menggunakan kaedah ini dalam pengajaran di dalam kelas. Ledakan teknologi juga menjadikan kaedah ini lebih mudah dijalankan terutama apabila pelajar telah mempunyai peranti mudah alih sendiri. Perbincangan dan penyelesaian masalah tidak lagi terhad dalam kelas malahan boleh dibawa ke luar kelas dengan berkesan. Impak dari kaedah ini sememangnya terbukti dan diharap dapat menambah kefahaman serta kemampuan pelajar dalam menyelesaikan masalah yang berkaitan dengan Matematik. Implikasi dari kajian ini dapat memberikan gambaran yang menyeluruh tentang keberkesanan serta meyakinkan pensyarah dalam mengaplikasikan kaedah ini di dalam kelas. Kajian lebih lanjut boleh dijalankan bagi melihat kesesuaian flipped classroom dilaksanakan di sekolah terutama di peringkat menengah atas.

\section{Rujukan}

Albalawi, A. S. (2018). The effect of using flipped classroom in teaching calculus on students' achievements at university of Tabuk. International Journal of Research in Education and Science, 4(1), 198-207. https://doi.org/10.21890/ijres.383137

Al-Zoubi, A. M., \& Suleiman, L. M. (2021). Flipped classroom strategy based on critical thinking skills: Helping fresh female students acquiring derivative concept. International Journal of Instruction, 14(2), 791-810. https://doi.org/10.29333/iji.2021.14244a

Boevé, A. J., Meijer, R. R., Bosker, R. J., Vugteveen, J., Hoekstra, R., \& Albers, C. J. (2017). Implementing the flipped classroom: an exploration of study behaviour and student performance. Higher Education, 74(6),1015-1032.https://doi.org/10.1007/s10734-016-0104-y

Braun, B., Bremser, P., Duval, A. M., Lockwood, E., \& White, D. (2018). What does active learning mean for mathematicians?. In The Best Writing on Mathematics 2018 (pp. 169-178). Princeton University Press. https://doi.org/10.1515/9780691188720-015

Buch, G. R., \& Warren, C. B. (2017). The Flipped Classroom: Implementing Technology To Aid In College Mathematics Student's Success. Contemporary Issues in Education Research (CIER), 10(2), 109-116. https://doi.org/10.19030/cier.v10i2.9921

Butterworth, B., Varma, S., \& Laurillard, D. (2011). Dyscalculia: from brain to education. Science, 332(6033), 1049-1053.

Carter, C. L., Carter, R. L., \& Foss, A. H. (2018). The Flipped Classroom in a Terminal College Mathematics Course for Liberal Arts Students. AERA Open, 4(1), 233285841875926. https://doi.org/10.1177/2332858418759266

Cronhjort, M., Filipsson, L., \& Weurlander, M. (2018). Improved engagement and learning in flippedclassroom calculus. Teaching Mathematics and Its Applications, 37(3), 113-121. https://doi.org/10.1093/TEAMAT/HRX007

Dori, Y. J., Kohen, Z., \& Rizowy, B. (2020). Mathematics for Computer Science: A Flipped Classroom with an Optional Project. Eurasia Journal of Mathematics, Science and Technology Education, 16(12), 1-20. https://doi.org/10.29333/ejmste/9149 
DOI: https://doi.org/10.47405/mjssh.v6i10.1067

Farmus, L., Cribbie, R. A., \& Rotondi, M. A. (2020). The Flipped Classroom in Introductory Statistics: Early Evidence From a Systematic Review and Meta-Analysis. Journal of Statistics Education, 28(3), 316-325. https://doi.org/10.1080/10691898.2020.1834475

Foldnes, N. (2017). The impact of class attendance on student learning in a flipped classroom. Nordic Journal of Digital Literacy, 12(1-2), 8-18. https://doi.org/10.18261/ISSN.1891-943X-2017-0102-02

Froehlich, D. E. (2018). Non-technological learning environments in a technological world: Flipping comes to the aid. Journal of New Approaches in Educational Research, 7(2), 88-92. https://doi.org/10.7821/naer.2018.7.304

Immekus, J. C. (2019). Flipping Statistics Courses in Graduate Education: Integration of Cognitive Psychology and Technology. Journal of Statistics Education, 27(2), 79-89. https://doi.org/10.1080/10691898.2019.1629852

Jamaludin, N. I., Shahimi, S., Bibi, L., \& Hameed, M. (2020). Elemen Kepercayaan Sebagai Teras Sumbangan Melalui Pendanaan Awam Bertujuan Kebajikan. Asian Journal of Accounting and Governance, 13, 55-65. https://doi.org/10.17576/ajag-2020-13-05

Jaster, R. (2017). Student and Instructor Perceptions of a Flipped College Algebra Classroom. International Journal of Teaching and Learning in Higher Education, 29(1), 1-16.

Jeong, J. S., \& González-Gómez, D. (2021). Flipped-ocn method in mathematics learning to analyze the attitudes of pre-service teachers. Mathematics, 9(6). https://doi.org/10.3390/math9060607

Johnston, B. M. (2017). Implementing a flipped classroom approach in a university numerical methods mathematics course. International Journal of Mathematical Education in Science and Technology, 48(4), 485-498. https://doi.org/10.1080/0020739X.2016.1259516

Khan, K. S., Kunz, R., Kleijnen, J., \& Antes, G. (2003). Five steps to conducting a systematic review. Journal of the royal society of medicine, 96(3), 118-121.

Khan, R. N., \& Watson, R. (2018). The flipped classroom with tutor support: An experience in a level one statistics unit. Journal of University Teaching and Learning Practice, 15(3).

Li, Y. Bin, Zheng, W. Z., \& Yang, F. (2017). Cooperation learning of flip teaching style on the MBA mathematics education efficiency. Eurasia Journal of Mathematics, Science and Technology Education, 13(10), 6963-6972. https://doi.org/10.12973/ejmste/76878

Liew, P. H.,\& Matora, E. M. (2020). Persepsi dalam Penggunaan Flipped Classroom dalam Pengajaran dan Pemudahcaraan (Pdpc): Sorotan Literatur Bersistematik. Malaysian Journal of Social Sciences and Humanities (MJSSH), 5(12), 188-200.

Lopes, A. P., \& Soares, F. (2018). Perception and performance in a flipped Financial Mathematics classroom. International Journal of Management Education, 16(1), 105-113. https://doi.org/10.1016/j.ijme.2018.01.001

Maldonado, A. D., \& Morales, M. (2020). Modelling dependency structures produced by the introduction of a flipped classroom. Mathematics, 8(1), 1-13. https://doi.org/10.3390/math8010019

Moher D, Liberati A, Tetzlaff J, Altman DG, The PRISMA Group (2009) Preferred Reporting Items for Systematic Reviews and Meta-Analyses: The PRISMA Statement. PLoS Med 6(7): e1000097. https://doi.org/10.1371/journal.pmed.1000097

Moreno, D., Palacios, A., Barreras, Á., \& Pascual, V. (2020). An assessment of the impact of teachers' digital competence on the quality of videos developed for the flipped math classroom. Mathematics, 8(2). https://doi.org/10.3390/math8020148

Nielsen, P. L., Bean, N. W., \& Larsen, R. A. A. (2018). The impact of a flipped classroom model of learning on a large undergraduate statistics class. Statistics Education Research Journal, 17(1), 121-140.

Novak, J., Kensington-Miller, B., \& Evans, T. (2017). Flip or flop? Students' perspectives of a flipped lecture in mathematics. International Journal of Mathematical Education in Science and Technology, 48(5), 647-658. https://doi.org/10.1080/0020739X.2016.1267810

Pozo Sánchez, S., López Belmonte, J., Fuentes Cabrera, A., \& López Núñez, J. A. (2020). Factores incidentes en el profesorado para la elección del aprendizaje invertido como referente metodológico. Educar, 57(1), 223-240. https://doi.org/10.5565/rev/educar.1152

Romero-García, C., Buzón-García, O., \& Touron, J. (2019). THE FLIPPED LEARNING MODEL IN ONLINE EDUCATION FOR SECONDARY TEACHERS. Journal of Technology and Science Education, 9(2), 109-121. 
Salas-Rueda, RA. Use of flipped classroom in the marketing career during the educational process on financial mathematics. Educ Inf Technol (2021). https://doi.org/10.1007/s10639-021-10470-x

Shinaberger, L. (2017). Components of a Flipped Classroom Influencing Student Success in an Undergraduate Business Statistics Course. Journal of Statistics Education, 25(3), 122-130. https://doi.org/10.1080/10691898.2017.1381056

Tisdell, C., \& Loch, B. (2017). How useful are closed captions for learning mathematics via online video? International Journal of Mathematical Education in Science and Technology, 48(2), 229243. https://doi.org/10.1080/0020739X.2016.1238518

Turra, H., Carrasco, V., González, C., Sandoval, V., \& Yáñez, S. (2019). Flipped classroom experiences and their impact on engineering students' attitudes towards university-level mathematics. Higher Education Pedagogies, 4(1), 136-155. https://doi.org/10.1080/23752696.2019.1644963

Umam, K., Nusantara, T., Parta, I. N., Hidayanto, E., \& Mulyono, H. (2019). An application of flipped classroom in mathematics teacher education programme. International Journal of Interactive Mobile Technologies, 13(3), 68-80. https://doi.org/10.3991/ijim.v13i03.10207

Wasserman, N.H., Quint, C., Norris, S.A. et al. Exploring Flipped Classroom Instruction in Calculus III. Int J of Sci and Math Educ 15, 545-568 (2017). https://doi.org/10.1007/s10763-015-9704-8

Wood, A. K., Bailey, T. N., Galloway, R. K., Hardy, J. A., Sangwin, C. J., \& Docherty, P. J. (2021). Lecture capture as an element of the digital resource landscape - a qualitative study of flipped and non-flipped classrooms. Technology, Pedagogy and Education, 00(00), 1-16. https://doi.org/10.1080/1475939X.2021.1917449

Zengin, Y. (2017). Investigating the use of the Khan Academy and mathematics software with a flipped classroom approach in mathematics teaching. Educational Technology and Society, 20(2), 89-100. 